\title{
Non Penal Policy of Terrorism Mitigation in Indonesia
}

\author{
Ali Masyhar ${ }^{1 *}$ \\ ${ }^{1}$ Criminal Law Departement, Faculty of Law Universitas Negeri Semarang, Semarang, Indonesia
}

\begin{abstract}
Thus far, prevention of terrorism has always been directed to penal policy that includes formulation/formulative policy, judicial/applicative policy and executive/administrative means. In fact, until now this penal policy has not indicated significant results. The penal policy only touches on the apparent symptoms on the surface, while the root of the problem (the attitude of radicalism) is never touched. Therefore, there should be another alternative to deal with the crime of terrorism that is clearly common enemy of humankind in any hemisphere. This paper tries to find other suggestion of counterterrorism other than those that have been conventionally conducted and even become the main focus in counterterrorism.
\end{abstract}

\section{Introduction and Literature Review}

Terrorism becomes a specter that haunts the peace and tranquility of human life. It is not only a ghost for big countries with their established economic level, but also for poor and developing countries. To this point, the prevention of terrorism has always been directed to penal policy. Penal policy is the rational efforts of the community against the emerging criminal acts, by using the means of criminal law. The criminal law means the use of criminal law, criminal justice process and criminal execution. Thus, the penal include formulation/formulative policy, judicial/applicative policy and executive/administrative means.

Based on the experience of Indonesia in dealing with terrorism by means of penal, it merely solves the problem of terrorism symptoms. It means that countermeasures through this penal path only put the outer shell target rather than substantively down to the root of the problem. This paper is about to make an alternative suggestion in the resolution of terrorism crime, not only for Indonesia but also any other countries.

\subsection{Non Penal Policy}

As described, that crime prevention efforts are not only conducted with the penal path. with terrorism, the beginning of its birth, this term is used as a tools to achieve justice [1]. According to G.P. Hoefnagels, crime prevention efforts can be pursued by [2]:

\footnotetext{
*Corresponding Author: ali_masyhar@mail.unnes.ac.id
} 
a. influencing the perspective of society on crime and punishment through mass media (influencing the perspective of society on crime and punishment/mass media);

b. criminal law application;

c. prevention without punishment.

Thus, in addition to criminal law application (penal policy), there is still a possible prevention without punishment (non-penal). Therefore, it is necessary to pay attention to other policy alternatives i.e. non-penal approach. Non-penal approach is intended as an attempt to cope with crime by means other than the penal law (non-penal). Crime prevention efforts using non-penal approach are oriented towards efforts to deal with conducive factors which induce the crime. Those categorized in this non-penal efforts are education, pengajian (communal quran reading) and other activities aimed at preventing the emerging crime.

Non-penal policy is a fundamental policy approach, as it is oriented to efforts in overcoming conducive factors to the cause of crime. Conducive factors include, among other things, social problems or conditions that directly or indirectly cause or nurture the crime [3]. The $8^{\text {th }}$ UN Congress in A/CONF.144/L.3 documents identifies the conducive factors that could lead to crimes [3]:

a. poverty, unemployment, illiteracy (ignorance), absence/lack of adequate housing and education systems and unsuitable/unmatched exercise;

b. an increase in the number of people who have no prospects (expectations) due to the process of social integration, as well as deterioration of social inequalities;

c. loosely social and family ties;

d. circumstances/conditions that make it difficult for people who emigrate to cities or other countries;

e. detriment or destruction of an indigenous cultural identity, together with racism and discrimination cause harm/weakness in the social, welfare and work environment;

f. decrease or deterioration (quality) of urban environments that encourage the increased crime and reduced (insufficient) services for neighborhood/environmental facilities;

g. difficulties for people in modern societies to integrate as they should within their community, family, workplaces or school environments;

h. abuse of alcohol, drugs and others of which use is also extended due to the abovementioned factors;

i. the spread of organized crime activities, in particular, drug trafficking and stolen goods storage;

j. impulses (especially by mass media) on ideas and attitudes that lead to the acts of violence, inequality or intolerance.

\subsection{Criminogenic Factors}

In addition to the above, dilemmatic conditions that should be watched out is development. The UN Congress on the Prevention of Crime and The Treatment of Offenders in its report of Sixth UN Congress 1981 [3], indicated that the development itself could be criminogenic if:

a. it was not rationally planned, or imbalanced planned, unbalanced/ inadequately planned;

b. disregarded cultural and moral values; and

c. did not include integrated social defense strategies.

Conducive factors that give rise to the above-mentioned crimes, obviously cannot be solved solely by penal policies (criminal policy with penal means), therefore they should be supported by non-penal policies.

Most strategic non-penal effort is every effort to create the community as healthy social and environmental settings (both in immaterial and material) of criminogenic factors (factors which induce crime). This means that the society with all its potential must become a crime- 
prevention or "anti-criminogen" factor, which is an integral part of completely criminal politics [3].

\section{Objective of The Study}

The main purpose of this study is to provide another alternative in the prevention of crime in Indonesia which has been centered on penal policy. This study encourages non penal policy to be an urgent and necessary policy, at least to be integrated with the penal policy.

\section{Methodology}

This study uses sociological/empirical/nondoctrinal research methods, although still not leaving the normative sphere. This is because perfect legal research, always synergize various disciplines [4]. This research uses three ways of collecting data, ie library/document study and observation. The proper method for understanding the meaning of the text is hermeneutics. Hermeneutics law is a method of interpretation of a text of law, rules of law, and the results of legal studies.

\section{Discussion}

\subsection{Non Penal Against Terrorism}

Criminal act of terrorism is unique, as its motive and causal factor is vastly different from the motives of other criminal acts. Occasionally, the crime of terrorism is conducted based on certain motives to be regarded.

Mark Juergensmeyer [5] in his book "Terror in the Mind of God: the Global Rise of Religious Violence" emphasized that terrorism is more often caused by the existence of cultures of violence within the society. Culture of violence owned by its supporting group therefore leads to the spirit of terrorized acts. Although such violent acts appear to be perpetrated by a single perpetrator, they have always had supportive and ideological networks that can legitimize or justify their actions. Salahuddin Wahid [6] stated that terrorism can be conducted with various motivations, namely for religious or ideological reasons, struggle for independence, liberation from injustice, and certain interest.

Similar to Salahuddin Wahid, A.C. Manullang [7] suggested that the triggers of terrorism are, among other things, religious, ideological, and ethnic conflicts and the widening gap between the riches and poors. In addition, the clogging of communications between the people and the government, rapidly increasing population, higher unemployment rate, increasing number of frustration generations, emergence of lonely people (lang weilich) (sic), the emergence of a new ideology of fanaticism, and separatism idea are fruitful land of terrorism acts.

Some of the triggers of terrorism are poverty and hunger. Fear of extreme hunger and poverty will easily ignite acts of violence and conflict, which is also a fertile land for the terrorism movement.

Terrorism acts, both in local and international scale, are also denials, resistances or counter-reactions that a group reflects in a limited or widespread environment due to common ideas and perceptions of the world economic system that they perceive to be unequal, unfair and disadvantageous to majority of the world society, or other minority communities whose aspirations are channeled with the struggle of the movement.

The common ideas and perceptions do not necessarily belong to one group with a single command. Although the arising terrorist movements and actions do not always happen at the 
same time or simultaneously, the same level of concern over the reality of poverty and social inequalities around them, or the ongoing world system of injustice, has led to growing movements and acts of terrorism in a country, region and more broadly, the world.

Major concerns over the widespread reality of poverty and high levels of inequality within a country, as well as between a few developed countries and many underdeveloped ones in Asia, Latin America, the Middle East, Africa and even Europe are conditions that nourish the growth of terrorism movements and their actions in different parts of the world. However, acts of terrorism are not just monopolies belonging to underprivileged countries. Terrorism and radical movements also occur in wealthy and developed nations. Dissatisfaction or different treatment due to social envy continues to persist and develop between dominant groups and minority and marginalized groups (in developed countries). Being continuously marginalized in the long term due to central government policy, moreover because of the multilateral policy, makes the marginalized groups can no longer tolerate the situation through formal and legal channels, inducing them even more strongly to take alternative paths through violence.

The deep concerns to the persisted marginalization of underprivileged and underdeveloped groups and countries due to multilateral policy pressures and the enormous implications of globalization have resulted in proliferation of radical resistance groups.

Terrorism is a highly complex phenomenon. As violent political phenomenon, the setting of terrorism cannot be easily formulated. Violence can be conducted by individuals, groups or countries. Motivation of the perpetrators can be based on extremely complex reasons such as idiosyncratic, criminal or political. Goals or victims are not real targets, but only as part of a bullying, coercive, or propaganda tactic to achieve their goals.

\subsection{Balance of Counter-Terrorism}

However terrorism and other criminal acts shall be eradicated, but efforts to wipe them out are not as easy as combating conventional crimes. They must be able to maintain a balance between maintaining security on the one hand, and the other hand, they also must uphold human rights. This is because the countries today are pushing themselves toward democratic order.

The order of democracy prioritizes the advantages of persuasive, negotiation and tolerance means rather than using coercive, compulsion, and violence means. Consolidation of democracy can only be achieved when all political actors undertake democratic means as the only game in town in fighting for their interests. Democratic states are also always required to ensure freedom (liberty), in addition to the security of its citizens [8].

Ideally, crime prevention including terrorism must be an integral policy between penal and non-penal path. In addition, it also needs to integrate between criminal and social policies. That ought to be considered in integral policy is the concern for victims of crime. This is the true meaning of integral policy. Eradication of criminal acts of terrorism in Indonesia is not merely a matter of law and law enforcement, but also social, cultural, economic issue closely related to the resilience of a nation. Policies, preventive measures and its eradication must also aim to maintain a balance in the obligation to protect the sovereignty of the state, the rights of victims and witnesses, as well as the rights of suspects/defendants. In relation to the above factors/causes of crime, the UN has promulated a resolution stating [9]:

"Urge all members of the United Nations to take action in their power to eradicate life conditions that degrade human dignity and leads to crime, which includes unemployment, poverty, illiteracy (ignorance), racial and national discrimination and various forms of social inequality" 


\section{Conclusion}

Based on the factors causing crimes in general and the motives of terrorism, non-penal policy can be taken to deal with the crime of terrorism. Non-penal policies are primarily directed at:

a. Alleviating poverty and unemployment, primarily at educated unemployment;

b. Increasing prosperity in justice;

c. Pressing the rate of population explosion;

d. Reducing the level of urbanization to cities or other countries;

e. Recovering damage or destruction of the indigenous cultural identity;

f. Reducing cells in terrorist organizations;

g. Detecting ideas and attitudes leading to terror and new ideological ideals at early stage;

h. Increasing public awareness of acts of terror.

i. Accommodating and developing tolerant attitude to different (political) principles;

j. Regarding and ensuring freedom to exercise its (religious) faith;

They need to be integrated together with penal policies. Even because of its more directed nature as a preventive effort, non-penal policy is possible to seek in the first place, preceding the penal policies, it takes so as not to get caught up in state terrorism which actually becomes dangerous terrorism [9].

\section{References}

1. Rapin, Ami-Jacques, Critical Studies on Terrorism 2, 2 Pp. 165-179 (2009)

2. Hoefnagels, G. Peter, Other Side of Criminology (Kluwer-Deventer, Holland, 1973)

3. B. N. Arief, Bunga Rampai Kebijakan Hukum Pidana (Citra Aditya Bakti, Bandung, 2002)

4. B. N. Arief, Penelitian Hukum Normatif (Suatu Upaya Reorientasi Pemahaman) (Universitas Jenderal Soedirman, Purwokerto, 11 - 15 September 1995)

5. Juergensmeyer, Mark, Terror In The Mind of God: The Global Rise of Religious Violence (Tarawang Press, Yogyakarta, 2003)

6. Akaha, A. Zulfidar (ed), Terorisme dan Konspirasi Anti Islam (Pustaka Al-Kautsar, Jakarta, 2002)

7. Manulang, M. Fernando, Menggapai Hukum Berkeadilan (Kompas Media Nusantara, Jakarta, 2007)

8. Imparsial, UU Antiterorisme: Antara Kebebasan dan Keamanan Rakyat (Imparsial, Jakarta, 2003)

9. R. Jackson, Critical Studies on Terrorism 1, 3, Pp. 377-392 (2008). 